MATHEMATICAL ASSOCIATION

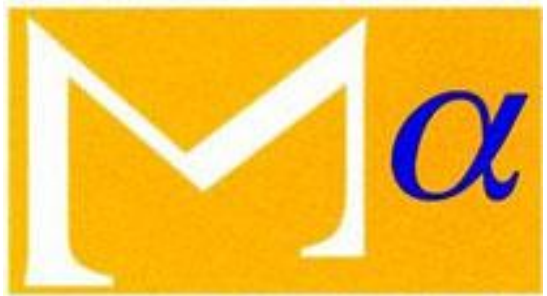

supporting mathematics in education

The Work of a Local Branch

Author(s): W. H. H. Hudson

Source: The Mathematical Gazette, Vol. 8, No. 121 (Jan., 1916), pp. 215-219

Published by: Mathematical Association

Stable URL: http://www.jstor.org/stable/3602723

Accessed: 20-12-2015 09:26 UTC

Your use of the JSTOR archive indicates your acceptance of the Terms \& Conditions of Use, available at http://www.jstor.org/page/ info/about/policies/terms.jsp

JSTOR is a not-for-profit service that helps scholars, researchers, and students discover, use, and build upon a wide range of content in a trusted digital archive. We use information technology and tools to increase productivity and facilitate new forms of scholarship. For more information about JSTOR, please contact support@jstor.org. 


\section{Prof. H. W. Lloyd Tanner, F.R.S.}

The following passage is taken from the Anniversary Address, to the Royal Society, delivered by Sir William Crookes, November 30, 1915 :

"Mathematical Science has lost one of its most distinguished exponents by the death of Prof. Henry William Lloyd Tanner, to whose educational and administrative talents the University of South Wales and Monmouthshire is deeply indebted. His views on the mathematical training of students were thoroughly sound, and his services to education were by no means limited to his College or University. In addition to his teaching and administrative work at Cardiff he published many important investigations in mathematics, dealing firstly with the solution of partial differential equations, and secondly with the theory of numbers. These latter researches, which were distinguished by great ingenuity and originality, were not by any means completed when failing powers forced him to resign his professorship and cease work."

Over the well-known signature E. B. E. appears a notice in the Proceedings of the London Mathematical Society (Ser. 2, vol. 14, pp. xxxvii-xxxviii), from which we extract a few felicitous passages :

"He organised well, taught devotedly, and endeared himself to colleagues and to generation after generation of students. Given a difficult administrative problem, Tanner was the man to face it ; given a wayward cutter of lectures, Tanner was the last to lose and the first to reclaim him ; given a social effort in student life or a college entertainment to be got up, his was the youthful merry soul which boyish life made its ally. ... He was a wise protector of others, but far too unsparing of himself."

He was respected for his intellectual honesty by all who knew him, and endeared to his many friends, no less by his geniality and ready wit, than by the inexhaustible sympathy of his unselfish nature.

\section{THE WORK OF A LOCAL BRANCH.}

\section{By the late Prof. W. H. H. Hudson, M.A.}

We meet to-day * to inaugurate a London Branch of the Mathematical Association. This is a step in a process of evolution.

The Mathematical Association is a continuation of the Association for the Improvement of Geometrical Teaching, commonly known as the A.I.G.T., founded in 1870 .

I did not join the Association till 1883, but some of its earliest reports are in my possession; to these I shall refer.

It owed its existence to a profound wide-spread dissatisfaction with the lack of geometrical knowledge, and still more the absence of geometrical power, displayed by students who had passed through the ordinary school course of Euclid.

The first report, in January 1871, shows that Dr. Hirst was President ; Archdeacon Wilson and Dr. Joshua Jones, Vice-Presidents; Dr. Wormell, Treasurer; Messrs. Levett and MacCarthy, Secretaries. There appears also a list of 12 Local Secretaries; this foreshadows what is going on now, the formation of local branches.

\footnotetext{
* 27th November, 1909.
} 
These were :

$\begin{array}{lll}\text { Messrs. Merrifield, } \\ \begin{array}{l}\text { Tucker, } \\ \text { Laverty, }\end{array} & \begin{array}{l}\text { London. } \\ \text { Oxford. }\end{array} & \text { Messrs. } \begin{array}{l}\text { Bushell, } \\ \text { Duckworth, Tiverton. }\end{array} \\ \begin{array}{l}\text { J. F. Moulton, Cambridge. } \\ \text { Mann, }\end{array} & \begin{array}{l}\text { Eve, } \\ \text { Miller, }\end{array} \\ \begin{array}{l}\text { Edinburgh. } \\ \text { T. S. Aldis, }\end{array} & \begin{array}{l}\text { Huddersfield. } \\ \text { Manchester. }\end{array} & \begin{array}{l}\text { Puckle, } \\ \text { Richardson, Windermere. }\end{array}\end{array}$

The first roll of members contained 43 other names.

The first officers of the Association may be accounted its founders, and as such are entitled to our reverence. Several have passed away. It would have been more fitting if some one of those who survive had filled the chair which I unworthily occupy to-day.

J. M. Wilson had written in the Educational Times in 1868, and about the same time Dr. Jones in a pamphlet, both powerfully in favour of reform. Messrs. Levett, Wormell and Tucker, subsequently secretary, had written letters to Nature in 1870.

The Association has had an uninterrupted succession of energetic and devoted secretaries, which continues to the present time.

At the same date, 1870, the British Association was also moving in the direction of the reform of teaching Geometry. As our business to-day concerns our own Association, I omit any further reference to the British Association, important as their proceedings were.

In the earliest writings the word Reform was generally employed. At the first meeting of the Association the word used in the title was changed to Improvement on the express ground that Reform might be ephemeral, but Improvement would always be needed. Can any one say that there is no need for it now?

From the first the main Improvement contended for was the discontinuance of the use of Euclid's Elements as the sole text-book of Geometry. This object has been attained ; Euclid has been dethroned, but it may still remain a question whether all the Improvement that was hoped for has or has not taken place. It was admitted in the arguments that were used that the main fault was that of learning by heart the exact words of a particular translation of Euclid's book. If this fault has not been corrected, the mere substitution of another text-book can avail but little. The worship of the letter killeth.

Messrs. Levett and MacCarthy say, in December 1873, that mathematical teachers " knew from their own experience that the majority of those who 'learnt Euclid' never exercised in the study any faculty except the memory, and that they not only failed to solve for themselves geometrical exercises, but were unable to reproduce a train of reasoning that was set before them unless they were supplied with the very words in which to exhibit the argument."

And in another place: "The average boy is capable of nothing further than the reproduction of a number of propositions in the words of his text-book; he breaks down when he is asked to do the simplest deduction"; and they go on to attribute this to the retention of Euclid as a text-book.

Was it not, however, due to the abuse of the text-book? It will be interesting to know whether the present generation of teachers find that better results follow from the use of the modern text-books that have been adopted in place of Euclid's. If they are learnt by heart as Euclid's was, I shall be surprised if there is any improvement.

The earliest effort of the Association was to produce first a syllabus of a geometrical text-book, issued privately in 1873, and in 1875 to the public, followed by proofs of the propositions in the Syllabus, the 
first part of which appeared in 1883 and the second in 1886. Simultaneously with the preparation of these proofs, which form an Elementary Treatise, they were busy endeavouring to induce examining bodies to admit other proofs than those of Euclid, and to test knowledge as well as memory. In 1877 they sent a letter of application to a large number of examining bodies asking that their examinations should be guided by the Syllabus of the Association.

In these endeavours they had some success, but they did not get all they asked for. Oxford was for a long time immovable, but even Oxford gave way at last. I remember Mr. Langley showing me with pride the first Rider that he believed had ever appeared in an Oxford Smalls Geometry paper. I am not certain of the date, but it must have been after 1892 .

The Association gradually enlarged its domain. It added to its work in 1878 the subjects of Higher Plane and of Solid Geometry and of Geometrical Conics, very natural and proper extensions, entirely in accord with its title. Subsequently, in 1883, it took up the subject of Arithmetic, one of its prominent members explaining that this was quite justifiable, since Arithmetic was necessary to the measurement of the earth.

In 1886 Mechanics began to occupy its attention. It has now absorbed the whole field of School Mathematics. This being the case, and the first object, the deposition of Euclid, having been practically accomplished, the Association in 1897 shortened its name to that which we now adopt-The Mathematical Association.

This brief historical retrospect shows that the aim of the London and other branches of the Mathematical Association is to continue the work of endeavouring to improve Teaching, and indicates that its scope does not include endeavours to extend the boundaries of mathematical knowledge. This function is appropriate to the London Mathematical Society.

The extension of the activities of the Association from the improvement or reform of teaching Geometry to that of Mathematics in general does not preclude the consideration of the teaching of what used to be known officially as Natural Philosophy and colloquially as Mixed or Applied Mathematics, but now is more commonly included under the title of Physics. The subject of Mechanics has already been annexed.

It would be a retrograde movement to limit the Association to Pure Mathematics. The dissociation of Pure and Applied Mathematics, which is a distinguishing feature of the regulations of the University of London, is calculated to have a prejudicial effect on the elementary study of both.

It has been one of the difficulties of mathematical teaching that the school-boy's mind, reflecting perhaps the opinions of ignorant elders who ought to have known better, is often imbued with the belief that Mathematics are useless. Elementary Mechanics is a great aid in exorcising that spirit of unbelief. I think I have noticed that practical Mechanics in the use of the bicycle has been of service in this respect.

Greatly increased attention has been given of late years to the Theory of Teaching. It may well come within the scope of this Association to consider the doctrines of the experts on this subject, so far as they are applicable to the teaching of Mathematics, including Physics; and, when their exposition has been clouded by the use of metaphysical and psychological, technical but unfamiliar, terminology, to translate them into a language understanded of the people who have to exercise the Art of Teaching. 
The use of the fingers in education has been impressed on us by the success of the Kindergarten in the training of very young children, and by the improvement in reasoning capacity that has been shown by those who in actual workshops have learnt the necessity of accuracy, and have been accustomed to deal with things instead of or as well as remembering words. The way in which this may be utilised in the teaching of Mathematics and its limitation are properly included in the purview of our Association.

I say its limitation, for there is a real danger of its being carried too far. It is too interesting. Greatly as interest facilitates the advancement of knowledge, progress can seldom be made if only what is interesting is to be studied. It is in the incipient and the advanced stages that interest is of most importance. In the incipient there is little else to appeal to, in the advanced there is too much else to distract. In the middle or school-boy stage, in order to prepare for the duties of life, one of the lessons that should be learnt is the subjection of inclination to duty.

Considering specially the subject of Geometry, all agree with the propriety of beginning with the use of ruler and compasses, which was neglected by those who learnt Euclid's propositions by heart and didn't know that Euclid wrote about Geometry. It is a question that needs solution in the practical working of every school to decide how far and for how long this preliminary practice should continue, and to what extent it should be carried on simultaneously with the study of geometrical relations in their theoretical aspect as propounded by Euclid or any other writer.

Another question concerning this subject can scarcely be considered to be settled, and may perhaps still form a suitable subject for discussion by the Association. Are we to depart from "the purity of the ancient geometry by transforming geometrical theorems into algebraic formulae, that is to say by substituting in place of concrete magnitude-such as lines, angles, superficies, volumes-their respective measures "? I quote from a document issued by the Italian Government in 1871, quoted by Dr. Hirst in his Presidential Address in 1872.

Dr. Hirst referred to this as "striving after a deceptive facility of treatment by the introduction of algebraical processes in place of geometrical reasoning."

Is there not something to be said on the other side ?

It is interesting to note that Dr. Hirst, in this address and that of the previous year, referred to the dissatisfaction in France and Italy with the text-books that had been used in place of Euclid's, and mentioned that the Italian Government in 1867 felt themselves obliged to re-establish the use of Euclid's Elements in the Gimnasi and Licei in order to "purge from Italian schools the many worthless books which private enterprise had succeeded in introducing." The use of improved text-books is a result which we in England may hope for from the mutual assistance which mathematical teachers may give one another at meetings such as those of our Association rather than from Government interference.

A propos of text-books, I may mention that this Association has a small library, which the formation of a London branch may have the effect of bringing into greater usefulness than in the past.

A question I have been often asked and scarcely ever been able to answer satisfactorily is, at what age this or that subject or part of a subject should be studied? An allied question is, what is the order in which mathematical subjects should be taken up ? and what is the best manner in which they should be interwoven? for I take it that it is now generally accepted that the watertight compartment 
doctrine is or deserves to be broken down. The use of letters in Arithmetic, of geometrical diagrams in Algebra, of the Differential Calculus in Algebraic Geometry, formerly tabooed, are now not only permitted but encouraged. Many questions of detail arise out of this extension.

The list of questions of detail that from time to time might receive the consideration of the Association could be indefinitely extended : improvements in processes, in arguments, in nomenclature, in definitions, and so on. Matters of detail, though they may seem of minor importance, affect very powerfully the success or failure of any art.

Since it may be expected that the London Branch will meet oftener than once a year, which has been the practice of the Association, I feel justified in suggesting matters of detail as worthy of being included in the scope of the work of the branch. Particular problems of interest need not be excluded.

Nor can we neglect the subject of examinations, though examinations should be kept out of sight in teaching.

Experience shows that, even if they are disregarded by the teacher, the eye of the pupil will be only too fixedly directed to them.

Where the examination schedule exercises a pernicious influence on study, such as those in Geometry, which our energetic predecessors have more or less succeeded after long struggle in ameliorating, this Association may with propriety by protest and entreaty continue that good work.

Where the schedule is satisfactory, and sometimes it is the more satisfactory the less it is detailed, the examination papers may be at fault, they may be of too great length, a very common mistake in Cambridge, or they may tend themselves too readily to the encouragement of cram, or they may have some other heinous fault.

In some such cases it might be fitting for the Association to call attention to it.

The examinations of the University of London naturally fall under the notice of the London Branch, and it is possible that the regulations and advice to teachers of the London County Council and the Board of Education might merit attention. Representations to public bodies would, however, come with more propriety from the whole Association than from a single branch.

There is another aspect of our meetings. We are, or have been, all engaged in the teaching of Mathematics, and we wish to improve that teaching, our own as well as other people's. We meet for mutual improvement. United by this bond, there will arise as we meet together a feeling of comradeship in the battle in which we are engaged, fighting always against ignorance, often against idleness, and sometimes against prejudice.

This camaraderie may be further promoted if a social character, at all events in part, is given to our meetings. For some years our annual meeting has been accompanied by a dinner. A distinguished friend of mine, well known to most of you, has told me of an ancient mathematical society to which was attached the soubriquet of "The 3 P's," because each man had his Pipe, his Pot and his Problem.* We shall not precisely imitate that, but I see that Tea is included in the agenda.

\footnotetext{
* The Mathematical Society, 1717-1845. "Its habitat was Spitalfields, and I think most of its existence was passed in Crispin Street. It was originally a plain society, belonging to the studious artisan. The members met for discussion once a week ; and I believe I am correct in saying that each man had his pipe, his pot and his problem." De Morgan, Budget of Paradoxes, Vol. I. p. 376. 2nd Edition, 1915. [W. J. G.]
} 